\title{
Monitoring the number of trips on open-ground tomatoes
}

\author{
Natalya Tyutyuma ${ }^{1 *}$, and Anastasia Bondarenko ${ }^{1}$ \\ ${ }^{1}$ Federal State Budgetary Scientific Institution «Precaspian Agrarian Federal Scientific Center of Russian Academy of Sciences», \\ 416251, Astrakhan region, Chernoyarsky district, the village of Solenoye Zaimishche, North quarter, 8
}

\begin{abstract}
The agroclimatic resources of the Astrakhan region are quite large and represent huge opportunities in the production of heat-loving crops such as vegetables and melons. The region has accumulated a great scientific and production experience in the cultivation of tomatoes as the main vegetable crop rotation crop.

To date, the first task for farmers of the region is to develop new modern agrotechnological techniques to eliminate the spread of thrips on open-ground tomato plants. The object of research was a hybrid of tomato of the domestic selection of the agricultural company Sedek Azhur F1. Materials and methods.

For the first time, for the conditions of light chestnut soils on the land use territory of FSBNU "Caspian Agrarian Scientific Federal Scientific Center of the Russian Academy of Sciences" during 20182020. the influence of various insecticides in the fight against tripasmi was studied.

As a result of the analysis, the presented scientific article presents the main results for the study of new modern insecticides in the fight against trypses on open-ground tomato Azhur F1. According to the results of three years of study, the optimal option with the use of the drug Confidor Extra was revealed, which contributes to a significant decrease in the number of phytophages.

The use of these preparations had no phytotoxic effect on open-ground tomato plants. In the version using the insecticide Confidor Extra, there was more purely commercial fruits and a significant increase in the crop relative to control without treatments, as well as a variant where the Fufanon-Nova preparation was used. The increase relative to control in the high-yield version was $+40.8 \mathrm{t} / \mathrm{ha}$ or $43.5 \%$.
\end{abstract}

\section{Introduction}

Trips is the most serious pest of vegetable crops [4-7; 916]. Crop damage depends on many factors: the size of the thrips, the size of its population, the phase of plant development for the period of plant damage, the duration of the period of damage.

To date, about 7,700 species of thrips have been recorded [8]. Trypses have piercing and sucking types of oral parts. As a result, they damage crops either during the absorption of food or by huge ovipositors.

Today, one of the promising areas for the development of a system of protective measures in the fight against trips is the use of new insecticides in modern agricultural technologies.

\section{Materials and methods}

The research was carried out on the experimental fields of the Federal State Budgetary Scientific Institution «Precaspian Agrarian Federal Scientific Center of Russian Academy of Sciences».

As an object of research, open ground tomato of the Sedek agrofarm Azhur F 1 was used. The study material was the drugs Confidor Extra and Fufanon Nova.
The scheme of experience included the following options:

V-1. Control - without processing.

V-2. Fufanon Nova. The norm of application is 13 $\mathrm{ml} / 101$ of water. Spraying during vegetation. Operating fluid flow rate - up to $11 / 10 \mathrm{~m} 2$.

$\mathrm{V}-3$. Extra's confidence. The norm of application is $1.5 \mathrm{~g} / 101$ of water (L). Spraying during vegetation. Operating fluid flow rate - up to $1-1.51 / 10 \mathrm{~m} 2$.

The area of experimental dividers is $25 \mathrm{~m} 2$, accounting - $10 \mathrm{~m} 2$. Location of subdivisions: rendomized in triple repetition.

The predecessor before laying the field experience was spring barley of the Ratnik variety. Soil treatment of the test site was carried out according to zonal recommendations. Autumn soil treatment began with a spill of 2 tracks, following grain harvesting.

Autumn plowing was carried out to a depth of 22-24 $\mathrm{cm}$, with a plow ПН-4-35. Spring tillage began as the soil matured physically. Spring rescue was carried out to a depth of 22-24 cm with a plow ПН-4-35. Closing of spring moisture and simultaneous leveling of the field surface were carried out by heavy disc harrows diagonally of the site. Fertilizers were introduced under the first spring cultivation to a depth of $10-12 \mathrm{~cm}$. In

\footnotetext{
* Corresponding author: pniiaz@mail.ru
} 
total, a cultivation 2 was carried out by the cultivator КПС-5.

The day before the landing of the seedlings in the field, machining with $\Phi-200+$ MT3-80 was carried out. Then the drip tapes were laid out. Before laying the field experience, a complex mineral fertilizer azofosc (N16P16K16) was introduced at a rate of $400 \mathrm{~kg} / \mathrm{ha}$.

The seedling landing rate in open ground is 40.8 thousand units/ha. The landing scheme at double-sided placement is $1.4 \times 0.30 \mathrm{~m}$. The landing method is manual (seedlings); irrigation method - drip irrigation system. Care for culture consisted in maintenance of a hybrid of a tomato F1 Openwork in a state, clean from weeds, and regulation of the water mode of the soil. Irrigation of the test site was carried out by drip method.

\section{Research Methodology}

Phytophages were counted 4 times for vegetation according to the Methodological Guidelines for Registration Tests of Insecticides, Acaricides, Mollusks and Rodenticides in Agriculture [3].

The yield accounting and structure were carried out with 10 registered plants from each plot according to the Manual on the conduct of registration tests of agrochemicals in agriculture [2], as well as the Methodology of the State Variety Testing of Crops [1].

\section{Research results and discussion}

\subsection{Agrochemical characteristics of soil}

The soil of the experimental site is a light chestnut subtype solonetzic. The actual content of humus along the horizon is $0-20 \mathrm{~cm} 0.88 \%$, pHKCL - 7.64.

Content of ammonium $\mathrm{N}-5.2 \mathrm{mg} / \mathrm{kg}$, nitrate $\mathrm{N}-30$ $\mathrm{mg} / \mathrm{kg}$, mobile $\mathrm{P}-27 \mathrm{mg} / \mathrm{kg}$ of soil, exchange $\mathrm{K}-260.0$ $\mathrm{mg} / \mathrm{kg}$ of soil.

\subsection{Biometric indicators}

Biometric measurements carried out during the period of butonization did not reveal any significant differences in the experience options. The average height of tomato plants for the study period 2018-2020. was in the range of $45.3-47.8 \mathrm{~cm}$, the number of lateral shoots was 3.0-4.0 pes.

The number of brushes 3.0 pcs. Per 1 plant. In the full flowering phase, a similar situation was observed, the average height of the plant was approximately the same 49.2-50.6 cm (within the error). In the fruiting phase, the maximum height of $58.5 \mathrm{~cm}$ of plants was fixed on the version with the test preparation V-3. Extra's confidence. The number of lateral shoots and the number of brushes on 1 plant was approximately equal.

\subsection{Crop structure elements}

Harvest accounting for repetitions was carried out 5 times per vegetation from 10 registered plants of each plot. According to the results of the analysis, the V-3 option stood out.

Extra's confidence. The total number of fruits for five fees was 182.0 pcs., Of these, 173.0 pcs were marketable with a total weight of $31.7 \mathrm{~kg}$, while on other versions they turned out to be much less - from 148 to $158 \mathrm{pcs}$. At the same time, the weight of commercial fruits was 22.0-

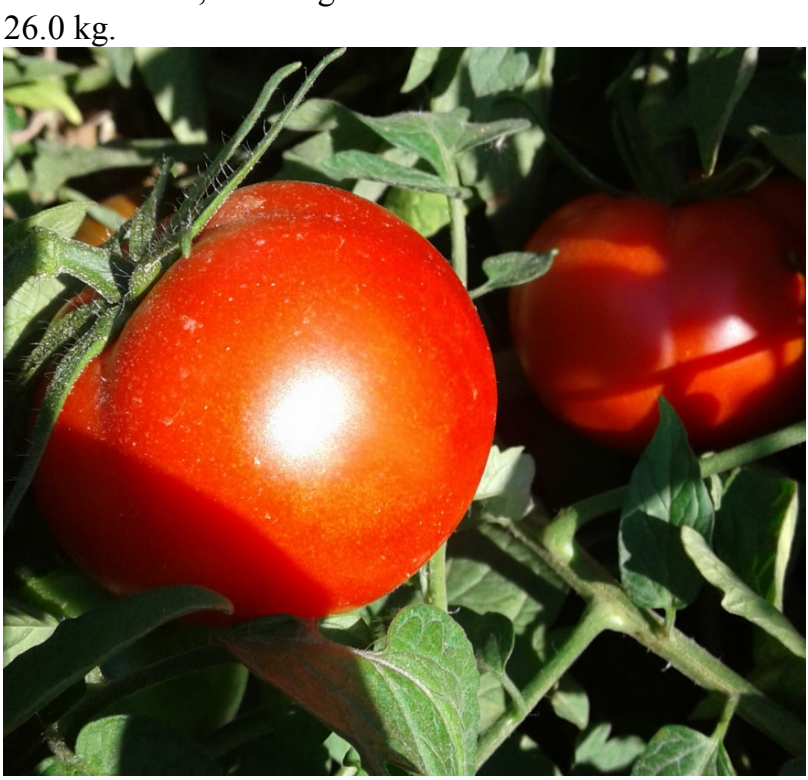

Fig. 1. Tomat Azhur F1

The mass of fruits from 1 plant, also, in the version $\mathrm{V} 3$ was maximum, and was equal to $3.3 \mathrm{~kg}$. At the same time, under the control without treatments, it was $2.3 \mathrm{~kg}$, and on the version with the treatment of Fufanon-Nova $2.7 \mathrm{~kg}$. The average weight of the fruit according to the test versions was in the range, for all versions, from 153.4 to $183.0 \mathrm{~g}$, the average number of fruits per 1 plant. was equal to $16.0-18.0$ pcs. All the results obtained were mathematically processed.

According to the "Methodological guidelines for registration tests of insecticides, acaricides, molluscides and rodenticides in agriculture," an assessment of the quality and quantity of crops is not carried out in our studies, we still tried to take this indicator into account.

The yield according to the test variants was 93.8 tons/ha, according to the V-2 variant. Fufanon-Nova $110.2 \mathrm{t} / \mathrm{ha}$, in the version V-3. Confidence Extra - 134.6 tons/ha. The increase relative to control in the high-yield version was $+40.8 \mathrm{t} / \mathrm{ha}$ or $43.5 \%$.

Accounting of phytophages on tomato open 1 soil Azhur F1. As a result of the analysis of Table 1, it was revealed that the average number of trips per escape before treatment with drugs on the control version and on other experimental versions was 10-11 pcs.

On the third day after treatment with the drugs presented in the experiment, their number decreased significantly. In the V-2 variant. Fufanon Nova already had an average of 6.0 units, which led to a decrease in numbers by $51.1 \%$. In the V-3 variant. Their number was 2.5 units, which led to a significant decrease in the number of phytophages by $79.6 \%$.

According to the "Methodological Guidelines for Registration Tests of Insecticides, Acaricides, 
Molluscocides and Rodenticides in Agriculture," trypes were counted on the seventh day after treatment with drugs. As a result, a reduction in these types of pests on the shoots of Azhur tomato was recorded F1 both on the version V2 to 5.5 pcs, which amounted to $57.7 \%$, and on the version $\mathrm{V} 3$ to 2.3 pcs, which amounted to $82.3 \%$.

After two weeks, for 14 days after treatments, a visual inspection and counting of trypes on tomato plants was carried out similarly.
A slight growth of this pest was noted. Number of phytophages in variant V-2. Fufanon Nova averaged 9.8 units, in version V-3. Confidentiality Extra 6.3 pcs.

It should be noted that on the control version, thrips were also counted. From the initial reading of 11 pcs on the escape there was a significant increase to 21.3 pcs on the escape (for 14 days), which amounted to almost $93.6 \%$.

Table 1. Biological Effectiveness of Confidor Extra in the Fight against Trips on Open Ground Tomato, Average for... 2018- 2020

\begin{tabular}{|c|c|c|c|c|c|c|c|c|}
\hline \multirow{3}{*}{$\begin{array}{l}\text { Experience } \\
\text { Variant }\end{array}$} & \multirow[t]{3}{*}{ frequency } & \multicolumn{4}{|c|}{ Average number of trips per escape, pcs. } & \multirow{2}{*}{\multicolumn{3}{|c|}{$\begin{array}{l}\text { Reduction of the number } \\
\text { relative to the initial one, } \\
\text { adjusted for control after } \\
\text { processing according to the } \\
\text { days of accounting, } \%\end{array}$}} \\
\hline & & \multirow[t]{2}{*}{ Before processing } & \multicolumn{3}{|c|}{$\begin{array}{l}\text { After processing by day of } \\
\text { accounting }\end{array}$} & & & \\
\hline & & & 3 & 7 & 14 & 3 & 7 & 14 \\
\hline \multirow{5}{*}{$\begin{array}{c}\text { V-1. Control } \\
\text { - no } \\
\text { processing }\end{array}$} & $\mathrm{I}$ & 10 & 13 & 16 & 23 & - & - & - \\
\hline & II & 11 & 15 & 14 & 18 & - & - & - \\
\hline & III & 11 & 14 & 14 & 18 & - & - & - \\
\hline & IV & 12 & 12 & 13 & 26 & - & - & - \\
\hline & Average & 11 & 13,5 & 14,3 & 21,3 & - & - & - \\
\hline \multirow{5}{*}{$\begin{array}{c}\text { V-2. } \\
\text { Fufanon } \\
\text { Nova }\end{array}$} & I & 8 & 5 & 5 & 9 & 49,1 & 51,9 & 41,9 \\
\hline & II & 12 & 6 & 5 & 11 & 59,3 & 68,0 & 52,7 \\
\hline & III & 10 & 7 & 6 & 9 & 43,0 & 53,8 & 53,5 \\
\hline & IV & 10 & 6 & 6 & 10 & 51,1 & 53,8 & 48,4 \\
\hline & Average & 10 & 6,0 & 5,5 & 9,8 & 51,1 & 57,7 & 49,4 \\
\hline \multirow{5}{*}{$\begin{array}{c}\text { V-3. } \\
\text { Confidence } \\
\text { Extra }\end{array}$} & I & 8 & 2 & 3 & 6 & 79,6 & 71,1 & 61,3 \\
\hline & II & 9 & 3 & 2 & 7 & 72,8 & 82,9 & 59,8 \\
\hline & III & 12 & 3 & 2 & 7 & 79,6 & 87,2 & 69,9 \\
\hline & IV & 9 & 2 & 2 & 5 & 81,9 & 82,9 & 71,3 \\
\hline & Average & 10 & 2,5 & 2,3 & 6,3 & 79,6 & 82,3 & 67,5 \\
\hline NSR 05 & & 3,2 & 1,4 & 1,2 & 3,6 & & & \\
\hline
\end{tabular}

\section{Conclusion}

1. The use of the test drug in the control of tyres led to a significant reduction in the pest for escape after treatments. The decrease in numbers relative to the initial one, adjusted for control after processing according to the days of accounting, was: by 3 days. $79.6 \%$, by 7 days $-82.3 \%$, by 14 days. $-67.5 \%$.

2. The use of the insecticide Confidor Extra, with a drug consumption rate set by the manufacturer, gave a significant yield increase of $+40.8 \mathrm{t} / \mathrm{ha}$ or $43.5 \%$ relative to the control option.

\section{References}

1. Ministry of Agriculture of the Russian Federation (Methodology of the State Variety Testing of Crops. Production of the fourth potato, vegetable and melon crops. (Moscow, 2015)

2. Ministry of Agriculture of Russia Methodological Guide for Conducting Registration Tests of Agrochemicals in Agriculture: A Practical Production Publication (Moscow, 2018)

3. All-Russian Research Institute for Plant Protection Methodological guidelines for registration tests of insecticides, acaricides, mollusks and rodenticides in agriculture (St. Petersburg, 2004)

4. Atilaw, Wondimagegn. Acta Phytopath. et Entomologica Hungarica Fighting Behaviour of Male Onion Thrips, Thrips tabaci (Thysanoptera: Thripidae) Lineages 55120 (2020)

5. M.M.Davidson, R.C. Butler, D.A.J. Teu lon J. Econ. Entom. Pyridine compounds increase thrips (Thysanoptera: Thripidae) trap capture in an onion crop 10241468 (2009)

6. M.M.Davidson, R.C. Butler, S. Winkler, D.A.J. Teulon New Zealand Plant Protectю Pyridine compounds increase trap capture of Frankliniella occidentalis (Pergande) in a covered crop $\mathbf{6 0} 156$ (2007)

7. L. Degola, I. Jansons, V. Šterna Agr. Research Effect of replacement of coated barley grain with hulless barley in diet on growth, carcass and meat quality traits of fattening pigs 19(X) (2021)

8. Kumar, Bhupendra \& Omkar, Omkar Thrips. Polyphagous Pests of Crops 373 (2021)

9. R. McPherson J. of econ. ent. Incidence of Thrips and Tomato Spotted Wilt Tospovirus in Flue-Cured Tobacco Protected from Early Season Insect Pest Infestations 99764 (2006) 
10. Monge-Pérez, José Eladio. Affiliation: Univ. of Costa Rica Thrips palmi en melón (2021)

11.H.R. Pappu R.A.C. Jones, R.K. Jain Virus Res.Global status of tospovirus epidemics in diverse cropping systems: Successes achieved and challenges ahead 1412219 (2009)

12. Raut, Ankush \& Pal, Satinder \& Wahengbam, Johnson \& Banu, Najitha $\mathrm{J}$ of Entomol. Res. Population dynamics of onion thrips (Thrips tabaci lindeman, Thysanoptera; Thripidae) and varietal response of onion cultivars against onion thrips 44 547 (2021)

13. Singh, Subash \& Kumar, Sanjeev \& Pathania, Mandeep \& Singh, Paramjit. J of Entomology Population dynamics of thrips tabaci lindeman in bt cotton. Indian (2021)

14. R. Smatas Agr. Res. The occurrence and control of aphids and thrips in winter triticale 4379 (2006)

15. Thangavel, Tamilnayagan. Int. J of Curr. Microbiol. and Appl. Sci. Screening of Different Germplasm against Groundnut Bud Necrosis Virus (GBNV) and Thrips in Tomato 62497 (2017)

16. Tyler-Julian, Kara \& Funderburk, J.E. \& Olson, S.M. \& Paret, M.L. \& Webster, Craig \& S. Adkins, Acta Horticulturae A stimulo-deterrent method of thrips and Tomato spotted wilt virus management in tomatoes 1069251 (2015) 